\title{
A MAP OF CURRENT RESEARCH TRENDS WITHIN TECHNOLOGY MANAGEMENT IN THE LIGHT OF SELECTED LITERATURE
}

\author{
Alicja Ewa Gudanowska \\ Bialystok University of Technology, Faculty of Management, Poland \\ Corresponding author: \\ Alicja Ewa Gudanowska \\ Bialystok University of Technology \\ Faculty of Management \\ International China and Central-Eastern Europe Institute of Logistics and Service Science \\ Tarasiuka 2, 16-001 Kleosin, Poland \\ phone: $(+4885)$ 746-98-96 \\ e-mail: a.gudanowska@pb.edu.pl
}

Received: 10 October 2016 Accepted: 24 January 2017

\section{ABSTRACT}

The objective of the analysis conducted and described in this article was to take a closer perspective of the contemporary research trends that refer to the discipline of technology management. The Author based the analysis on keywords defined by the authors of the publications that refer issues of technology management. Scopus was the database which provided data for the analysis. The Author focused on publications indexed in the selected database in 2011-2016. The resulting database keywords have been ordered and partially aggregated. Based on them, the VOSviewer tool was used to prepare a graphical presentation of frequency and co-occurrence with the rest of the analysed group. The analysis led to an indication of current research trends within the discipline of technology management.

KEYWORDS

technology, technology management, research trends, visualisation, map of research trends.

\section{Introduction}

Knowledge on technologies is one of the elements shaping the economic development $[1,2]$. All industrial branches, sectors as well as business functions are transformed through these technologies [3]. Technology can be perceived as a tool, a system, and value [4]. The contemporary concept of technology is an all the more complex system [5], being inherent to machines and appliances that are at a root of a production system but also to goods manufactured with the use of a given technology [6, 7]. According to Musango [8], the development of the contemporary technology is defined by four characteristics: uncertain, dynamic, systemic and cumulative. The uncertainty is associated with the existence of numerous solutions to a given problem. It is difficult to provide an unambiguous identification as to which solution is best in terms of all economic, social, technological, environmental and other factors. Technology and its development are dynamic; technology changes with time (exemplified by the shape and analysis of the $S$ curve [9]). Moreover, the development of technology cannot be treated as a separate, isolated phenomenon connected only with technology (the systemic quality of the development of technology). Mutual interactions exist between the simultaneous occurrences of technological, institutional and social changes. On the other hand, the cumulativeness of the development of technology results from the continuous technological transformation that is based on the preceding experiences and acquired knowledge $[5,8,10]$.

The complexity of the technology itself and numerous aspects of its development, both observed by many scientists, determine the need for the necessary and valid actions aimed at searching for the adequate manner of technology management (TM) [6]. It is one of the most difficult tasks that specialists and engineers currently face [11], since, in its nature, 
technology management is a multi-disciplinary concept [12]. It involves many research trends that concern subjects from various disciplines, and it appears interesting to analyse, which of them are developed by the contemporary scientists.

This paper expands on the previous paper by the Author presented at the 7th International Conference on Engineering, Project and Production Management (EPPM2016). The conference paper was aimed at analysing the areas of interest within TM that change with time. The analysis was based on the data from the Web of Science database, which led to the fact that terms, such as innovation or product development, proved to be inseparable from the concept of technology management. Other issues, such as knowledge management, have been evolving from being a secondary, complementary area of interest into becoming one of the major research trends. Many interesting research areas (e.g. network analysis in the context of intellectual property and technology innovation, or the application of technology management in the field of healthcare) appeared only recently and might also develop into the next main research trends in the future [13]. The objective of this paper is to take a closer look at the current research trends that occur in scientific papers that were published within the last five years. The paper presents an analysis of the data from the Scopus database, where the number of registered publications related to the TM issue appeared higher than in the case of the Web of Science database. The study also involved the preparation and analysis of a map of research trends, based on the data generated from the Scopus database.

\section{Technology management - the development and relations with other disciplines}

The interest in technology management as a research field has grown considerably, particularly in the last 15-20 years, though it already dates back to the $1950 \mathrm{~s}$. This interest became an independent discipline [4] together with the appearance of professional organisations, such as PICMET (Portland International Centre for Management of Engineering and Technology) and EITIM (European Institute for Technology and Innovation Management) [14]. According to Beyan and Cetindamar, the number of papers on this issue published in the years 1995-2005 grew by over $160 \%$, as compared to the preceding years (since 1986) [15].

According to Eunarski, provision of an unambiguous TM definition is hampered by the diversity of generally applied technologies and the use of this term in various situations [7]. As Moczała indicates, the development of technology results from the innovativeness, discoveries, scientific principles, data, and experiences being the effect of production processes [16]. Innovations, technological in particular, can be found in scientific research and technical outputs produced by centres, also manifest in the form of information in available publications and papers, information that can be gathered at fairs, exhibitions and scientific meetings, as well as new structures of products, technologies and organisations, inventions and improvements achieved in an enterprise. Therefore, the signals for technological changes can be triggered both from the internal structures of the organisation as well as external sources $[16,17]$. Nonetheless, regardless of the source of innovation, it is important to strive and use as well as manage the occurring technological change, which, according to Hejduk and Grudzewski, constitutes the core of technology management, characterised by the ability to apply the latest scientific achievements [18].

In a historical overview of the technology management discipline presented in 1997, Drejer pointed to four schools associated with its development: R\&D management, innovation management, technology planning, and strategic management of technology. These schools were interrelated as they constituted a mutual inspiration for mastering and creating new theories. Nevertheless, each of them followed their own individual path [4] (Table 1).

Table 1

Schools of management of technology - the scope and issues [4].

\begin{tabular}{|c|c|c|}
\hline Sch & & \\
\hline \begin{tabular}{l|} 
School 1: \\
RED \\
management
\end{tabular} & se & $\begin{array}{l}\text { peopie, ideas, iunds, cur- } \\
\text { ture }\end{array}$ \\
\hline \begin{tabular}{l|} 
School 2: \\
Innovation \\
management
\end{tabular} & $\begin{array}{l}\text { manage innovation } \\
\text { in the entire com- } \\
\text { pany }\end{array}$ & $\begin{array}{l}\text { conception, invention } \\
\text { and exploitation of } \\
\text { technology }\end{array}$ \\
\hline $\begin{array}{l}\text { School 3: } \\
\text { Technology } \\
\text { planning }\end{array}$ & $\begin{array}{l}\text { manage technology } \\
\text { across the compa- } \\
\text { ny }\end{array}$ & $\begin{array}{l}\text { analyse and plan the } \\
\text { complex process of tech- } \\
\text { nological development }\end{array}$ \\
\hline $\begin{array}{l}\text { School 4: } \\
\text { Strategic } \\
\text { MOT }\end{array}$ & $\begin{array}{l}\text { manage and inte- } \\
\text { grate technology } \\
\text { with other aspects }\end{array}$ & $\begin{array}{l}\text { deal with all the di- } \\
\text { mensions of technologi- } \\
\text { cal evolution }\end{array}$ \\
\hline
\end{tabular}

As a discipline, TM was evolving and so were the principal areas of interest within its scope $[13,14]$. At present, this involves not only the concentration on managing the technological innovation, but also (as Cetindamar, Phaal and Probert claim) six areas of activity that technology managers must perform in their daily work: identification of technology, selec- 
tion, acquisition, exploitation, protection and learning the knowledge coming from the development and exploitation of technologies [19]. Therefore, technology management can be described as directed at the effective execution of the enumerated activities undertaken to achieve and maintain (or increase) a high market position, based on the objectives of the organisation [20]. The definition addresses two significant issues within technology management: (1) establishing and maintaining relations between technological resources, and the objectives of the organisation is of paramount importance and a regular challenge for companies, which requires effective communication and knowledge management, supported by the adequate procedure and tools; (2) effective technology management requires the execution of processes that do not always need to be visible in the organisation $[14,21]$.

Technology management should not be limited to managing a specific set of technologies, but it should also develop the strategy of their implementation in the aspect of available resources, currently applied technologies, the future of the market and a social and economic environment [22, 23]. According to Badawy, technology management comes down to the practice of integrating a technological strategy into the business strategy in a company, an integration requiring a sensible coordination of research and production, as well as the function of marketing, finances and human resources in a company [24]. Klincewicz identifies the fields of interest, within which the researchers focused on technology management: (1) an aspect of appearing new technologies and their impact on current activities and development of the enterprise; (2) an identification of opportunities and threats in the context of development of technologies, particularly emerging ones; (3) observation and analysis of the activities of other market participants, particularly with regard to the results of conducted research and development; (4) decision making within conducting and coordinating individual research and development activities as well as the development of technological products; (5) indication of technology with strategic and tactical aspects; (6) preparation of technology products to market; (7) development of competence in selected areas, or (8) the protection of industrial and intellectual property of an enterprise [25]. According to the research conducted by Cetindamar et al., the authors dealing with technology management are focused on the following topics: (1) an organisation, its culture, structure, competences, knowledge, creativity, idea of management; (2) a policy within technology, i.e. policies and systems of technology management, systems of innovation in the national, regional and sector framework; (3) the acquisition of the technology, its transfer, diffusion, adaptation, and dissemination [26]. However, based on the analysis of selected publications from the periodical Technovation, Pilkington and Teichert indicated that the areas of research interests within TM are focused on the aspects of strategy and technology, national systems and differences, sources of competitive strategies, manufacturing/operations/new product development, knowledge management and inventors, patents, and lifecycles/change/discontinuity [27].

The management of technology discipline is more complicated than 40 years ago. At present, many disciplines are engaged in TM. In the light of the analysis conducted by Lee, technology management seems to have close relationships with six disciplines: (1) Business and Management, (2) Marketing, (3) Economics, (4) Planning and Development, (5) Information Science, and (6) Industrial Engineering and Operations Research. According to studies by Lee, the disciplines that contribute to TM the most are Business and Management, and Industrial Engineering and Operations Research. [12]. As Drejer claims, disciplines, such as project management, organisation theory, strategic management or innovation theory, still constitute disciplines per se; however, they are at the same time a part of technology management discipline, and, more significantly, they transform their contents and assumptions [4]. Therefore, it appears important to involve the knowledge on the types of research trends that currently co-occur in the context of TM for further development and shaping of the discipline.

\section{Current research trends within technology management - data selection and the assumed research procedure}

To analyse the current research trends among publications indicated by their authors as associated with the discipline of technology management, the Author verified the number of publications available in the Web of Science (WoS Core collection) and Scopus databases (Fig. 1). The number of articles that included references to the concept of technology management was 1,920 in the case of WoS database. However, the Scopus database had 3,860 papers that included titles, keywords or abstracts referred to TM. 


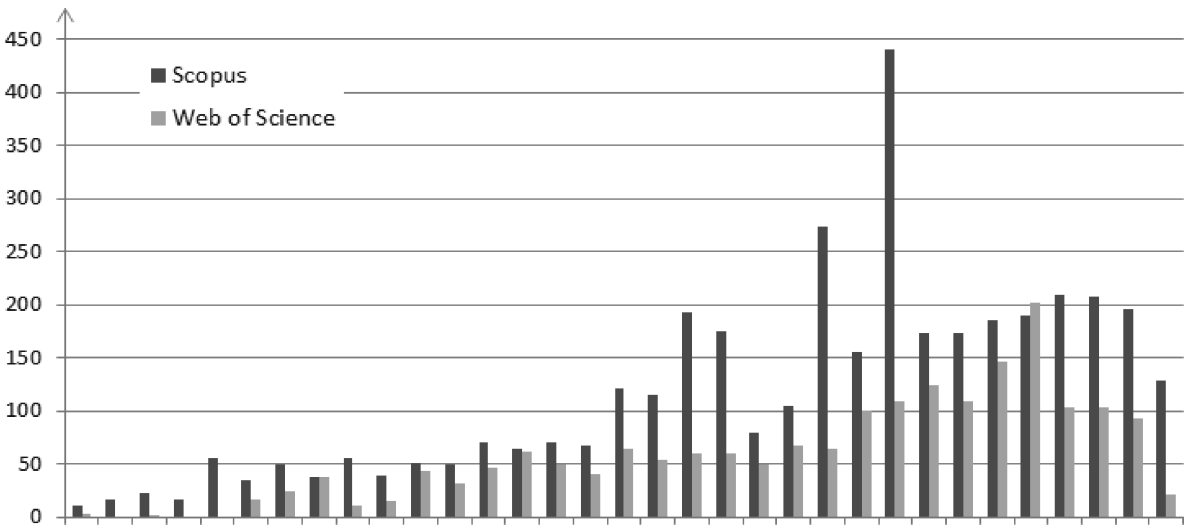

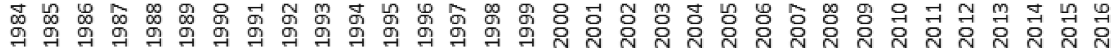

Fig. 1. Number of publications indexed in the Web of Science (WoS) and Scopus databases and referring to the concept of technology management.

The set of generated data in case of both databases contained articles, conference papers, books and book chapters. Figure 1 presents the number of publications indexed in the WoS and Scopus databases and referring to the concept of technology management. The chart refers to the period after 1983, when the number of publications exceeded ten items in the Scopus and three in WoS databases.

The Author opted for the Scopus database for further analysis, because of the numerousness of both generated sets. While analysing the number of publications indexed in the Scopus database, a considerable growth in the interest in the technology management subject could be observed. Moreover, it should be noted that in the last decade, the number of publications regularly exceeded 100 papers per year. It is interesting to note that in 2006 and 2008, the number of publications on the analysed subject was, respectively, 273 and 440 . The analysis of the cause of such a situation points to the fact that in both years, the number of published conference papers considerably exceeded the number of articles. Moreover, they comprised over $75 \%$ of all publications in a given year. In 2008, 290 papers were published as a result of a conference organised by the PICMET; and in 2006 , the number of papers was 192, which significantly affected the discipline's popularity within the analysed database in these years. Although the number of publications in the years 2009-2015 was lower than that of the two years, it was rather stable and around 190 papers annually. The lower number of publications was registered in 2016, which was most likely due to the timing of the analysis since the publishing year of 2016 had not yet closed at the time.

The general analysis of the subject areas, into which the articles in the Scopus database are classified, can lead to the interpretation that all the identified papers mainly represented two areas: business, management and accounting (1782 publications), and engineering (1585). The other areas, where the number of publications exceeded 100 papers were: computer science (915), decision sciences (776), social sciences (408), medicine (201), economics, econometrics and finance (153), chemical engineering (125), environmental science (104), and mathematics (101). The areas of materials science, earth and planetary sciences, energy and biochemistry, and genetics and molecular biology were represented by already less numerous groups of publications (Fig. 2).

\section{Business, Management wences and Accounting Computer Science ${ }^{\text {Mathemaics }}$ Decision Sciences chemical Engineening Engineering social Sciences}

Fig. 2. Tag cloud of the subject areas associated with TM in the Scopus database.

The areas most numerously represented in a collection of papers on TM were analysed in terms of changes in the number of publications in the subsequent years. The study of Fig. 3, representing the results of the analysis, points to the fact that until 2004, the most popular papers were those classified in the field of Engineering. Similar changes are observed in the area of Computer Science. Both fields enjoyed the largest number of publications after 2001. Following a significant fall in 2004, these disciplines have constantly been developing. Papers referring to TM that in 2005 appeared in the context of Business, 
Management and Accounting, virtually reversed the current situation for good (except for the year 2013). Since that time, this area has become the most popular within the analysed disciplines. An interesting situation can be observed in the case of Decision Science that appeared almost the best-represented by the papers on TM published in 2008 when the conference was organised by the PICMET. Interestingly, in 2006, when an analogous event took place, this was an area not as well-represented by the publications recorded in the Scopus database. Moreover, since 2009, a significant decrease in papers classified in this field has been observed. The chart also depicts a slowly, though stably growing trend within publications referring to TM and classified in the field of Social Science.

Many researchers from various countries as well as research and scientific units have incorporated the issue of technology management into their studies. Among the authors that publish in journals indexed in the Scopus database, there are also scientists that both frequently raise the issue of technology management as well as have their papers cited in other works within this scope.

Table 2 presents a list of authors that most frequently appeared in the analysed set of data as researchers focused on the development of the discipline of technology management. The table also shows the number of articles associated with TM that were indexed in Scopus database. It includes names of the researchers that published more than five articles in the analysed context.

\section{Table 2}

Authors that most frequently appeared in the set of publications associated with TM in the Scopus database.

\begin{tabular}{c|c||c|c}
\hline Author & $\begin{array}{c}\text { Number } \\
\text { of pubs }\end{array}$ & Author & $\begin{array}{c}\text { Number } \\
\text { of pubs }\end{array}$ \\
\hline Probert D.R. & 45 & Balestra G. & 7 \\
\hline Phaal R. & 40 & Schwieger D. & 7 \\
\hline Farrukh C.J.P. & 21 & Wu W. & 7 \\
\hline Pantano E. & 19 & Basoglu N. & 6 \\
\hline Schuh G. & 16 & Buys A.J. & 6 \\
\hline Berg D. & 14 & Hu P.J.H. & 6 \\
\hline Daim T. & 14 & Kwakkel J. & 6 \\
\hline Garcia R. & 14 & Ladwig C. & 6 \\
\hline Brent A.C. & 13 & Mallick D.N. & 6 \\
\hline Kocaoglu D.F. & 12 & Marshall L. & 6 \\
\hline Cunningham S.W. & 11 & Niwa K. & 6 \\
\hline Einspruch N.G. & 11 & Sbragia R. & 6 \\
\hline Jun S. & 11 & Sen S. & 6 \\
\hline Porter A.L. & 10 & Tian L. & 6 \\
\hline Granstrand O. & 9 & Tschirky H. & 6 \\
\hline Yu B. & 9 & Weng C.S. & 6 \\
\hline Baretich M.F. & 8 & \multicolumn{2}{|l}{} \\
\hline Cetindamar D. & 8 & & \\
\hline Pretorius L. & 8 & &
\end{tabular}

The objective of the article was to take a closer look at the contemporary trends and make a more detailed analysis based on the publications issued within the last five years as well as within the period of the unfinished year of the analysis, i.e. the years 2011-2016 (1095 papers).

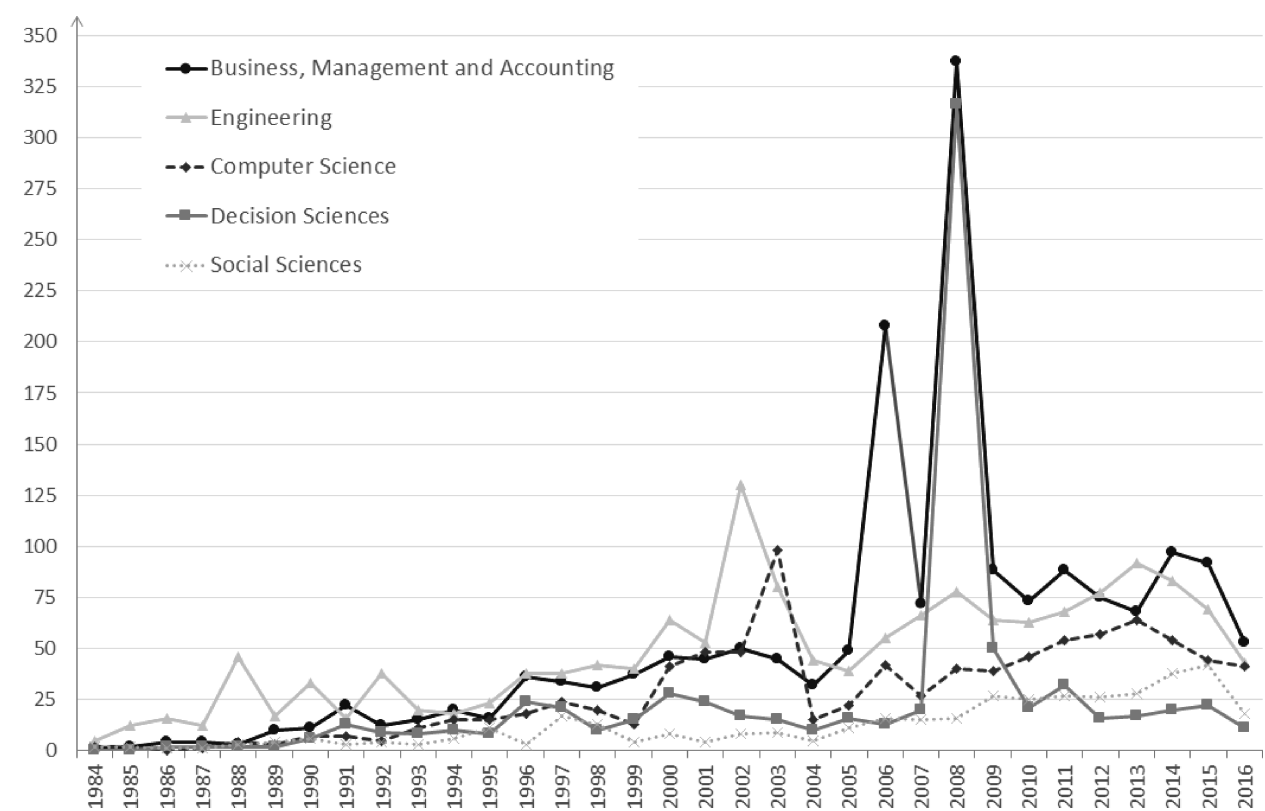

Fig. 3. Number of publications indexed in the Scopus database and referring to the concept of technology management classified in different areas. 
Keywords and their co-occurrence were the elements representing the content mentioned in the articles were. The analysis was based on the keywords included by the authors of the publications. To present a clear visualisation, this paper focuses on those expressions that appeared at least five times in a group of selected publications. The analysis also disregarded the terms technology management, management of technology, technology, and management, which constituted filters while selecting specific publications.

The data was organised and presented with the application of the VOSviewer program - software particularly useful while working with a large number of data. It facilitates the generation of visualisations of the gathered data from several perspectives. It is possible to highlight the aspect of the frequency of the occurrence as well as the frequency of their co-occurrence. The size of the elements presented on the maps points to the occurrence of particular keywords, whereas the connections between the nodes of the resulting network represent their co-occurrence in an analysed group of publications. The stronger the connection, the higher the frequency of the cooccurrence.

To present a map of research trends within TM, the analysis involved a manner of graphic presentation described as label view. Such a choice resulted from the fact that this view also indicates clusters that the analysed elements create. The clusters seen on the maps with labels, marked with colours, reflect the association of a given element to those that it exists with most frequently. At the same time, the same element can be a part of a different cluster, within which it nonetheless occurs more seldom [28].

\section{A map of current research trends within technology management}

Within the conducted analysis, the Author prepared a map of research trends associated with the TM discipline in the context of publications indexed in the Scopus database for the years 2011-2016. Figure 4 presents the resulting map. The central part of the map includes the most frequently occurring keywords. Also, the size of the nodes representing each of the appearing terms as well as the font size, in which the name of a given node is written, correspond to the frequency of the occurrence of a given term. The notions: innovation, information technology management, technology management strategies, innovation management, knowledge management, patent analysis, health technology management and technology transfer appeared most often in the analysed set of publications, and had the highest occurrence ratio (Table 3).

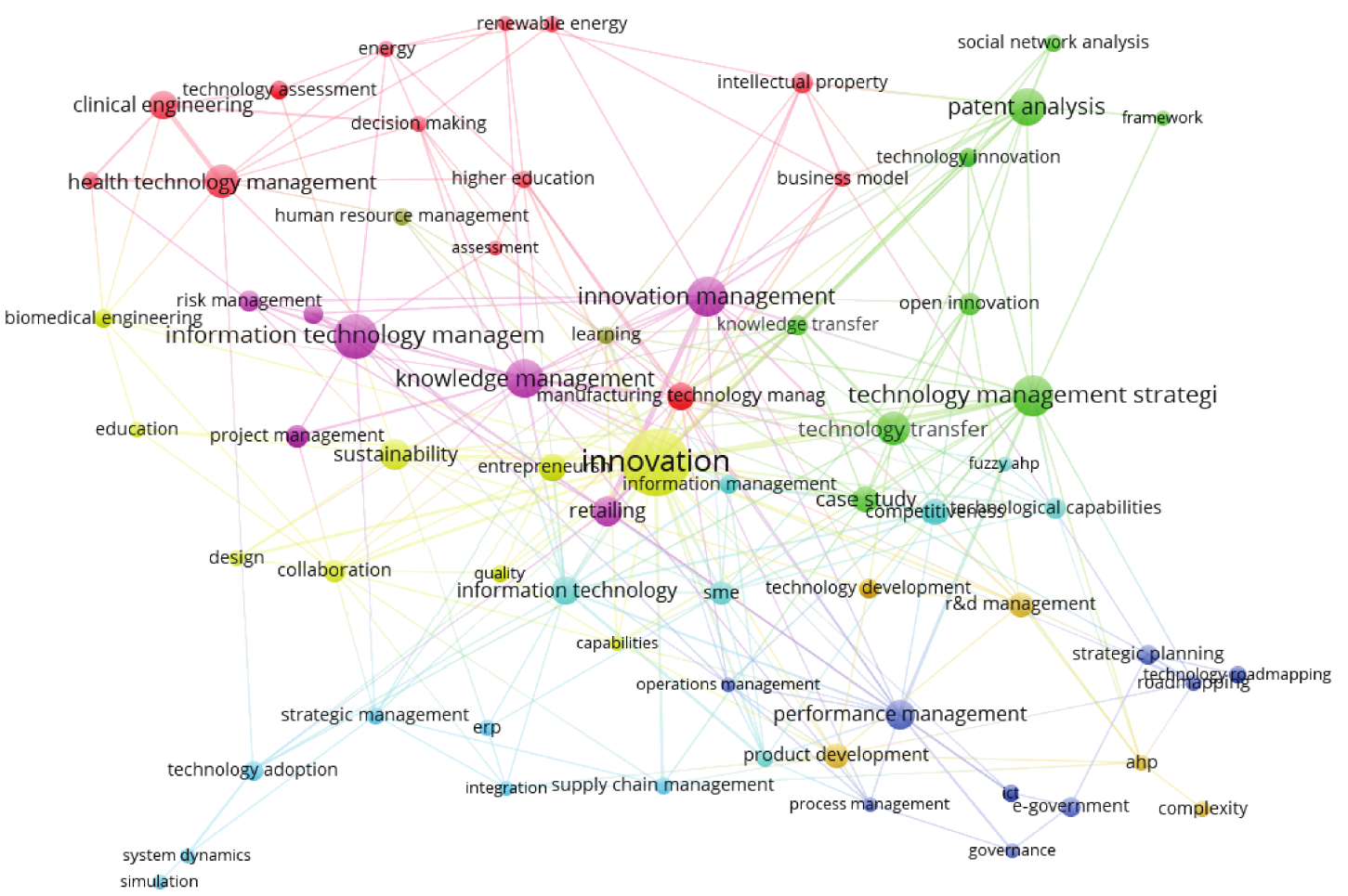

Fig. 4. Map of current research trends based on co-occurrence of the authors' keywords in publications referring to technology management from the Scopus database in the years 2011-2016. 
Management and Production Engineering Review

Table 3

Clusters identified through the analysis.

\begin{tabular}{|c|c|c|}
\hline KEYWORD & Ooccurrences & Co-occurrence \\
\hline \multicolumn{3}{|c|}{ CLUSTER 1} \\
\hline $\begin{array}{l}\text { health technology } \\
\text { management }\end{array}$ & 22 & 19 \\
\hline clinical engineering & 16 & 13 \\
\hline $\begin{array}{l}\text { manufacturing } \\
\text { technology } \\
\text { management }\end{array}$ & 12 & 14 \\
\hline intellectual property & 9 & 10 \\
\hline higher education & 7 & 10 \\
\hline business model & 6 & 9 \\
\hline decision making & 6 & 10 \\
\hline energy & 6 & 7 \\
\hline medical equipment & 6 & 8 \\
\hline renewable energy & 6 & 5 \\
\hline technology assessment & 6 & 3 \\
\hline assessment & 5 & 3 \\
\hline technology forecasting & 5 & 6 \\
\hline \multicolumn{3}{|c|}{ CLUSTER 2} \\
\hline $\begin{array}{l}\text { technology } \\
\text { management } \\
\text { strategies }\end{array}$ & 31 & 31 \\
\hline patent analysis & 26 & 15 \\
\hline technology transfer & 21 & 19 \\
\hline case study & 14 & 9 \\
\hline open innovation & 10 & 10 \\
\hline knowledge transfer & 8 & 13 \\
\hline social network analysis & 7 & 4 \\
\hline technology innovation & 6 & 8 \\
\hline framework & 5 & 2 \\
\hline
\end{tabular}

\begin{tabular}{l|c|c}
\hline \multicolumn{2}{c}{ CLUSTER 3 } \\
\hline $\begin{array}{l}\text { performance } \\
\text { management }\end{array}$ & 17 & 19 \\
\hline e-government & 8 & 3 \\
\hline strategic planning & 8 & 6 \\
\hline roadmapping & 6 & 8 \\
\hline governance & 5 & 4 \\
\hline ICT & 5 & 4 \\
\hline $\begin{array}{l}\text { operations } \\
\text { management }\end{array}$ & 5 & 9 \\
\hline process management & 5 & 7 \\
\hline technology \\
roadmapping & 5 & 2 \\
\hline & CLUSTER 4 & \\
\hline innovation & 73 & 80 \\
\hline sustainability & 18 & 15 \\
\hline entrepreneurship & 13 & 11 \\
\hline collaboration & 10 & 15 \\
\hline biomedical engineering & 6 & 7 \\
\hline design & 6 & 6 \\
\hline education & 6 & 4 \\
\hline capabilities & 5 & 8 \\
\hline quality & 5 & 5 \\
\hline
\end{tabular}

Table 3 [Cont.]

\begin{tabular}{|c|c|c|}
\hline KEYWORD & Ooccurrences & Co-occurrence \\
\hline \multicolumn{3}{|c|}{ CLUSTER 5} \\
\hline $\begin{array}{l}\text { information } \\
\text { technology } \\
\text { management }\end{array}$ & 35 & 12 \\
\hline innovation management & 29 & 34 \\
\hline knowledge management & 27 & 25 \\
\hline retailing & 17 & 18 \\
\hline risk management & 9 & 7 \\
\hline cloud computing & 8 & 6 \\
\hline project management & 8 & 4 \\
\hline \multicolumn{3}{|c|}{ CLUSTER 6} \\
\hline information technology & 16 & 25 \\
\hline competitiveness & 12 & 14 \\
\hline SME & 11 & 17 \\
\hline $\begin{array}{l}\text { technological } \\
\text { capabilities }\end{array}$ & 9 & 9 \\
\hline $\begin{array}{l}\text { information } \\
\text { management }\end{array}$ & 6 & 9 \\
\hline productivity & 6 & 13 \\
\hline fuzzy AHP & 5 & 3 \\
\hline \multicolumn{3}{|c|}{ CLUSTER 7} \\
\hline technology adoption & 8 & 7 \\
\hline strategic management & 7 & 8 \\
\hline $\begin{array}{l}\text { supply chain } \\
\text { management }\end{array}$ & 7 & 9 \\
\hline ERP & 6 & 4 \\
\hline integration & 5 & 6 \\
\hline simulation & 5 & 1 \\
\hline system dynamics & 5 & 4 \\
\hline \multicolumn{3}{|c|}{ CLUSTER 8} \\
\hline product development & 12 & 12 \\
\hline R\&D management & 12 & 10 \\
\hline technology development & 7 & 6 \\
\hline $\mathrm{AHP}$ & 6 & 8 \\
\hline complexity & 6 & 1 \\
\hline \multicolumn{3}{|c|}{ CLUSTER 9} \\
\hline $\begin{array}{l}\text { human resource } \\
\text { management }\end{array}$ & 7 & 4 \\
\hline learning & 7 & 13 \\
\hline
\end{tabular}

While analysing Fig. 4 it can be observed that the resulting network is quite dense and is characterised by numerous connections. The issues most strongly connected with others within the network were: innovation, innovation management, technology management strategies, knowledge management, and information technology (the highest co-occurrence ratio, Table 3).

As a result of the network visualisation, the applied software also allowed for the identification of the clusters, in which the most frequently occurring terms were found. The resulting nine clusters are presented in Table 3. 
The first resulting cluster (Cluster 1) was a group of issues associated, among other things, with the health sector. The most frequent and the most interrelated component in the cluster was health technology management. Here, this element exhibited a very strong relation with clinical engineering. However, both of them were associated with the aspect of medical equipment. In the same cluster, a trend connected with energy, renewable energy in particular, could be observed. Both areas - health and energy - were frequently connected with methodological issues, such as technology assessment or technology forecasting. In both areas, the authors also imposed the context of decision making on the deliberations presented in the publications. The same cluster showed some interest in the subject of intellectual property that appeared in the context of renewable energy as well as in the aspect of a business model. Here, manufacturing technology management is clearly shifted into the direction towards the centre of the map, which pointed to its numerous though weaker connections with a large number of other issues. The subject of higher education, associated with the area of health and energy could be observed less frequently as well.

The second classified cluster in VOSviewer (Cluster 2) involved issues that concerned one of the most tightly connected as well as most popular nodes in the network, i.e. technology management strategies. This cluster included as frequently co-occurring aspect of technology transfer - associated with the notion of case study, which points to the type of the conducted analyses within the enumerated subjects. A strong group in the cluster was deliberations associated with patent analysis, connected with the aspects of social network analysis and technology innovation. The presence of papers associated with knowledge transfer can also be observed as these are characterised with stronger connections with the elements of other clusters (such as innovation management or manufacturing technology management). Within the cluster, this term often occurred together with the notion of technology transfer and technology innovation. This cluster contains publications concerning the aspect of open innovation, mentioned in the context of technology innovation and technology transfer, but also intellectual property, SME or $\mathrm{R} \& \mathrm{D}$ management.

Another resulting cluster (Cluster 3) was a group concerning the issue of performance management, most often connected with operations management or the ICT context, but also frequently co-occurring with the components of other clusters, such as process management. Here, stronger connections could be observed between performance management and technology management strategies ascribed to Cluster 2, and the research group shifted to the margin of the network characterised by the notions of strategic planning, roadmapping and technology roadmapping.

The next cluster (Cluster 4) involved a general notion of innovation, which is the most strongly interconnected and most frequently occurring in the entire group. This term is strongly intertwined with the network, being the subject or context of many described deliberations presented in the analysed publications. Here, the strongest connections appear in the context of technology and knowledge transfer. The cluster combines a general aspect of innovation with, among other things, the contexts of sustainability, entrepreneurship, and collaboration (also being a subject of frequent deliberations in the set of the analysed publications).

Cluster 5 was another cluster focused near the map's centre. Here, the following terms frequently appeared in the entire set of publications: information technology management, innovation management, and knowledge management. The cluster also exhibited a strong connection of the notions of innovation management and retailing, which shows a frequent context of deliberations concerning innovation management. The aspect of information technology management was often combined with the context of risk management, and cloud computing, and less frequently with project management. Cluster 6 was one of the most dispersed clusters. The terms classified here were mostly connected with various areas (such as the issue of information technology or the frequently imposed context of SME or competitiveness).

The subsequent cluster (Cluster 7) concerned one of less frequently occurring keywords that characterise publications. Therefore, this cluster was located on the margins of the network. It involved the aspects perhaps not as strongly though numerously connected with others, i.e. strategic management or supply chain management, as well as a less frequent context of ERP, integration, system dynamics, and simulation.

Cluster 8 included terms more frequently occurring as characteristics of the publications, product development, and R\&D management. In the context of the latter notion, the analyses involved technology development combined with the notion of technology transfer or innovation management. It was observed that analysis relating to AHP was shifted towards the margins. 
The last cluster (Cluster 9) was comprised of human resource management appearing in the context of analyses connected with health technology management and knowledge management as well as the notion of learning that, though less frequently occurring as characteristics of publications, appeared quite strongly in association with the aspect of innovation and innovation management.

\section{Conclusions}

The publication period is one of the limitations of the conducted analysis that should be mentioned. The trends identified based on indexed papers in scientific databases show the image of a discipline with some delay. However, according to the Author, this is still one of just a few sources allowing for the agile and wide perspective of the issues undertaken by scientists as well as familiarising with the development directions of a given issue. Such analyses can be particularly useful for researchers at the beginning of their scientific work in a given discipline to properly recognise the areas already developed and commented in literature as well as observe potential niches that are worth confronting with personal scientific interests. Not every identified area of the conducted analyses may become a new leading research trend. However, the knowledge of scientific deliberations carried out in this field can inspire for the creation of an innovative vision of the issue in question.

The objective of the conducted analysis described in this article was to take a closer look at contemporary research trends that refer to the discipline of technology management.

In the first part of the analysis, the Author paid particular attention to the number of publications concerning technology management. In initial years, an interest in this subject was reflected in a slowly growing number of publications. An intensified growth in the number of papers in the field of TM occurred in 2002-2003 and 2006-2008. The growing interest in TM, which was recorded in initial years, systematically stabilised at the level of 150 publications annually. The stabilisation of the number of publications within the issue at a lower level compared to that when it was especially popular may suggest both higher requirements of proof-readers in this field and the change in the perception of the discipline (as an issue becoming less trendy but still worth of further exploration). Nonetheless, while analysing changes in the number of publications classified in various areas separated in the Scopus database in the years 19842016 , it could also be observed that despite the ini- tial predominance of papers within Engineering and a large interest in TM within Business, Management and Accounting after 2001, both fields consistently remained the most frequent areas of classification in terms of related papers.

In the second, which is the main part of the analysis, the Author considered the keywords defined by authors as the data that adequately represented deliberations, described in the articles indexed in one of the chosen databases of scientific papers. The analysis led to a strong visible trend of combining research that referred to technology management with the context of innovation and innovation management. This may appear to be a direction inseparable from TM, which is not surprising because that technology management by definition is to a large extent the management of technological innovation.

A strong research trend consisted of the analyses referring to the strategy of technology management as well as information technology management. An interesting area that was observed near the centre of the network was a trend oriented on the analyses connected with knowledge management. This is a context imposed on many analyses from various areas. According to the Author, these trends reflect changes in the perception of the entire process of technology management from narrowly directed at the technology itself to the process understood as covering many aspects and not only the technological ones.

Other interesting trends were also those that occurred on the margins of the map. Some of them were the issues of high occurrence, such as patent analysis or health technology management, which may become the leading trends in the discipline over a longer time perspective. From the perspective of looking for research gaps in the discipline of technology management, less frequently appearing areas that coexisted with areas that appeared often (such as social network analysis or fuzzy analytic hierarchy process) seemed interesting. These areas appeared to be characterised by the greatest potential of exploration and become the relevant point for seeking for innovative research trends or new concepts of the currently conducted research within the discipline of TM.

The analysis allows indicating technology management as a rapidly developing field of study, characterized by interdisciplinary issues with a great research potential. According to the Author, the analyses, such as the one presented here, aid in determining research trends that are developed within a given discipline, particularly when it is represented by numerous sets of publications. The perception in this respect allows the orientation in stores of knowledge 
gathered within the discipline, and fosters identification of research niches that are worth exploring.

The research was conducted within the scope of the project $S / W Z / 1 / 2014$ and financed from the funds of the Ministry of Science and Higher Education.

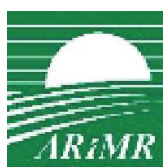

Tth International Conference on Engineering, Project, and Production Management (EPPM2016) was co-organised by the Agency for Restructuring and Modernisation of Agriculture (Poland).

\section{References}

[1] Mitchell G.R., Global technology policies for economic growth, Technological Forecasting and Social Change, 60, 3, 205-214, 1999.

[2] Halicka K., Innovative Classification of Methods of The Future-Oriented Technology Analysis, Technological and Economic Development of Economy, 22, 4, 574-597, 2016.

[3] 3 Utterback J., The Dynamics of Innovation, The Internet and the University, Aspen Institute Forum, Educase, 81-103, 2002.

[4] Drejer A., The discipline of management of technology, based on considerations related to technology, Technovation, 17, 5, 253-265, 1997.

[5] Sharif N., Technology innovation governance for winning the future, Technological Forecasting and Social Change, 79, 595-604, 2012.

[6] Łunarski J., Key processes in systemic technology management [in Polish: Kluczowe procesy w systemowym zarzadzaniu technologia], Technologia i Automatyzacja Montażu, 1, 2009.

[7] Łunarski J., Technology management. Evaluation and improvement [in Polish: Zarzadzenie technologiami. Ocena i doskonalenie], Oficyna Wydawnicza Politechniki Rzeszowskiej, Rzeszów, 2009.

[8] Musango J.K., Technology Assessment of Renewable Energy Sustainability in South Africa, PhD thesis, Stellenbosch University, Matieland, 2012.

[9] Lowe P., The Management of Technology: Perception and Opportunities, Chapman \& Hall, Londyn, 1995.

[10] Pretorius M.W., de Wet G., A model for the assessment of new technology for the manufacturing enterprice, Technovation, 20, 3-10, 2000.
[11] van Wyk R., Technology: The Forgotten Science, IEEE Engineering Management Review, 44, 3, 28$31,2016$.

[12] Lee H., Uncovering the multidisciplinary nature of technology management: journal citation network analysis, Scientometrics, 102, 51-75, 2015.

[13] Gudanowska A.E., Modern research trends within technology management in the light of selected publication, Procedia Engineering, 2017, in press.

[14] Cetindamar D., Phaal R., Probert D., Understanding technology management as a dynamic capability: A framework for technology management activities, Technovation, 29, 237-246, 2009.

[15] Beyhan B., Cetindamar D., No escape from the dominant theories: The analysis of intellectual pillars of technology management in developing countries, Technological Forecasting and Social Change, 78, 103-115 2011.

[16] Moczała A., Innovation management [in Polish: Zarzadzanie innowacjami], Wydawnictwo Akademii Techniczno-Humanistycznej w Bielsku-Białej, Bielsko-Biała, 2005.

[17] Międzynarodowe Centrum Nauki i Zaawansowanej Technologii ICS, Technology management. Course of technology transfer management [in Polish: Zarzadzanie technologia. Kurs Zarzadzania Transferem Technologii], UNIDO, available: www.uz.zgora.pl/ skotylak/kursy/ZT-part1.pdf. Last accessed 1st July 2015.

[18] Hejduk I., Grudzewski W., Technologies management: advanced technologies and challenge of their commercialization [in Polish: Zarzadzanie technologiami: zaawansowane technologie $i$ wyzwanie ich komercjalizacji], Difin, Warszawa, 2008.

[19] Cetindamar D., Phaal R., Probert D.R., Technology management as a profession and the challenges ahead, J. Eng. Technol. Manage., 41, 1-13, 2016.

[20] Phaal R., Farrukh C.J.P., Probert D.R., Technology roadmapping - A planning framework for evolution and revolution, Technological Forecasting and Social Change, 71, 5-26, 2004.

[21] Phaal R., Farrukh C.J.P., Probert D.R., A framework for supporting the management of technological innovation, Conference "The Future of Innovation Studies", Netherlands, 2001.

[22] Nazarko Ł., Responsible research and innovation - new paradigm of technology management, The 9th International Scientific Conference Business and Management 2016: Conference Proceedings, Vilnius, 2016. 
[23] Liao S., Technology management methodologies and applications. A literature review from 1995 to 2003, Technovation, 25, 381-393, 2005.

[24] Badawy M.K., Technology management education: alternatives models, California Management Review, 40, 4, 94-116, 1998.

[25] Klincewicz K., Technologies management: The case of blue laser [in Polish: Zarzadzanie technologiami. Przypadek niebieskiego lasera], Wydawnictwo Naukowe Wydziału Zarządzania Uniwersytetu Warszawskiego, Warszawa, 2010.
[26] Cetindamar D., Wasti S.N., Ansal H., Beyhan B., Does technology management research diverge or converge in developing and developed countries?, Technovation, 29, 45-58, 2009.

[27] Pilkington A., Teichert T., Management of technology: themes, concepts and relationships, Technovation, 26, 288-299, 2006.

[28] van Eck N.J., Waltman L., VOSviewer Manual. Manual for VOSviewer version 1.3.0, software documentation, 2011. 